\title{
Genetic diversity and differentiation among high-latitude broadcast-spawning coral populations disjunct from the core range
}

\author{
Annika M. E. Noreen ${ }^{1,2, *}$, Madeleine J. H. van Oppen $^{1}{ }^{1}$ Peter L. Harrison ${ }^{2}$ \\ ${ }^{1}$ Australian Institute of Marine Science, Townsville MC, Queensland 4810, Australia \\ ${ }^{2}$ Marine Ecology Research Centre, Southern Cross University, PO Box 157, Lismore, New South Wales 2480, Australia
}

\begin{abstract}
Little is known regarding the maintenance of range-edge populations in the absence of gene flow from core populations. In this study, we used 7 microsatellite markers to investigate genetic diversity and differentiation of the broadcast-spawning coral species Acropora solitaryensis among range-edge populations that are disjunct from the core range, and cautiously infer what this means in terms of connectivity. Acropora solitaryensis in sub-tropical eastern Australia is effectively isolated from conspecifics thousands of kilometers away and cannot rely on immigration from core populations for population maintenance. The range-edge region in this study consists of nearshore (Solitary Island) and offshore (Lord Howe Island) populations separated by $>630 \mathrm{~km}$. Despite the presence of null alleles, genetic diversity was within the range of that observed in other Acropora species. Nearshore and offshore populations were found to be genetically differentiated, with some indication of a small number of long-distant migrants in both directions. From both a demographic and a genetic perspective, this result may be important for the long-term persistence of $A$. solitaryensis at this range edge.
\end{abstract}

KEY WORDS: Acropora solitaryensis · Range edge $\cdot$ Long-distance dispersal · Genetic maintenance · Disjunct distribution

Resale or republication not permitted without written consent of the publisher

\section{INTRODUCTION}

Range-edge populations are hypothesized to be more vulnerable to extirpation compared with larger core populations. The underlying factors for this increased risk can be grouped into 2 broad categories: (1) demographic instability arising from marginal habitats, small populations, and random stochastic events (e.g. Hardie \& Hutchings 2010); and (2) genetic erosion (e.g. high inbreeding, low genetic diversity) that can contribute to lower fitness (Sexton et al. 2011 and references therein). Nevertheless, many ecologically and demographically marginal, genetically unique range-edge populations have survived over extended time scales (e.g. Budd \& Pandolfi 2010).
While many studies describe demographic and genetic relationships between range-edge and core populations (reviewed by Hardie \& Hutchings 2010), few studies have examined the mechanisms underlying maintenance of genetic diversity and population persistence at range edges, especially in the absence of immigration from a core range (reviewed in Eckert et al. 2008). Genetic as well as demographic factors must be taken into account when considering longterm persistence of range-edge populations disjunct from the core. At the scale of individual populations, several hypotheses have been proposed for longterm persistence at range boundaries. For example, genetic isolation in a substantially different (often marginal) habitat compared with the core range may preserve mutations and local adaptations that favor 
population persistence at that site (Kawecki 2008). Introgressive hybridization can also increase a species' genetic diversity, and is generally more common at species boundaries where species abundances tend to be lower compared with core populations (Thompson et al. 2010, Budd \& Pandolfi 2010). Finally, gene flow between genetically differentiated populations within a range edge can provide substantial genetic benefits, such as decreasing the effects of inbreeding and improving fitness (e.g. Sexton et al. 2011).

Extended metapopulations of reef corals may be maintained by gene flow among large numbers of interconnected reefs (e.g. Great Barrier Reef; Ayre \& Hughes 2000) or along 'stepping stone' populations (e.g. southeast African coast; Ridgway et al. 2008). For non-continuous reef areas (e.g. across a continental shelf), rare long-distance migration events may be significant in maintaining a metapopulation over evolutionary time scales (e.g. Underwood et al. 2009, Nakajima et al. 2012). Surrounding populations can be vital for recolonization after a localized extirpation in one population due to a stochastic event. Thus, dispersal between populations that are disjunct from the core range is likely to have positive demographic as well as genetic consequences.

This study provides population genetic data on subtropical populations of the broadcast-spawning coral Acropora solitaryensis (Acroporidae; Veron \& Wallace 1984). This species is one of the most ecologically important and numerically dominant coral species on subtropical Eastern Australian reefs and coral communities (Harriott et al. 1999). Acropora solitaryensis occurs at high-latitude Eastern Australian locations, is extremely rare on the Great Barrier Reef (GBR), but is common in the Coral Triangle, Japan, and in Western Australia (Wallace 1999). Hence, A. solitaryensis populations in subtropical Eastern Australia are both range edge and effectively isolated from conspecific core populations in the Coral Triangle, as the GBR is an improbable source and the next nearest populations are 1000s of kilometres distant.

This species has been observed to broadcast spawn gametes at both the Solitary Islands and Lord Howe Island (Wilson \& Harrison 2003, Harrison 2008). However, the large geographic distances between subtropical Eastern Australian nearshore coral communities and offshore reefs (>630 km) likely limit dispersal between these locations. The observation that 2 species of brooding reef coral among subtropical Eastern Australian locations showed limited gene flow supports this hypothesis (Miller \& Ayre 2008,
Noreen et al. 2009). A large proportion of subtropical-dwelling corals are tropical species surviving at or near their range limit, and environmental stress is known to negatively affect coral reproduction as well as survival (Harrison 2011). However, 2 characteristics of Acropora solitaryensis may result in higher dispersal compared with brooding coral species in this region: (1) broadcast-spawning species generally have larger distances over which routine dispersal occurs compared with brooding corals (e.g. Ayre \& Hughes 2000, Underwood et al. 2009), and (2) in contrast to many tropical species, A. solitaryensis's reproduction appears to be adapted to the cooler subtropical water temperatures (Nozawa \& Harrison 2007).

Using a population genetics approach, we examined (1) the genetic diversity of range-edge Acropora solitaryensis populations that are geographically isolated from conspecifics in the core range, and (2) the genetic differentiation between nearshore (Solitary Islands) and offshore (Lord Howe Island) range-edge locations. Our results are discussed in light of possible mechanisms underlying demographic and genetic maintenance of these A. solitaryensis populations and their overall persistence in this region.

\section{MATERIALS AND METHODS}

The 2 main locations sampled in this study were the nearshore Solitary Islands $\left(29.9\right.$ to $30.2^{\circ} \mathrm{S}$, $\left.153.4^{\circ} \mathrm{E}\right)$ and offshore Lord Howe Island $\left(31.5^{\circ} \mathrm{S}\right.$, $159.1^{\circ} \mathrm{E}$; Fig. 1). Middleton $\left(29.3^{\circ} \mathrm{S}, 159.1^{\circ} \mathrm{E}\right)$ and Elizabeth Reefs $\left(29.6^{\circ} \mathrm{S}, 159.1^{\circ} \mathrm{E}\right)$ were surveyed in 2007 to conduct sampling for this study, but no Acropora solitaryensis colonies were observed. Samples from the northern limit of the southeastern Australian range (Flinders Reef; $27.0^{\circ} \mathrm{S}, 153.4^{\circ} \mathrm{E}$ ) were also collected, but there were too few individuals for robust genetic analyses $(n=8)$. At Lord Howe Island, where species identification is more uncertain, larger voucher specimens were taken for subsequent verification of species identity, and C. C. Wallace was consulted in situ during the latter of 2 sample collections. The identity of the sampled corals was confirmed using the Australian Institute of Marine Science Scleractinia of Eastern Australia Monograph Series reference collection at the Museum of Tropical Queensland. Only confirmed A. solitaryensis samples were included in the study, which resulted in low sample sizes at Lord Howe Island. Pooling of sites occurred if they were adjacent $(<2 \mathrm{~km}$ distant), in similar habitat, located on the same side of the island (east or 


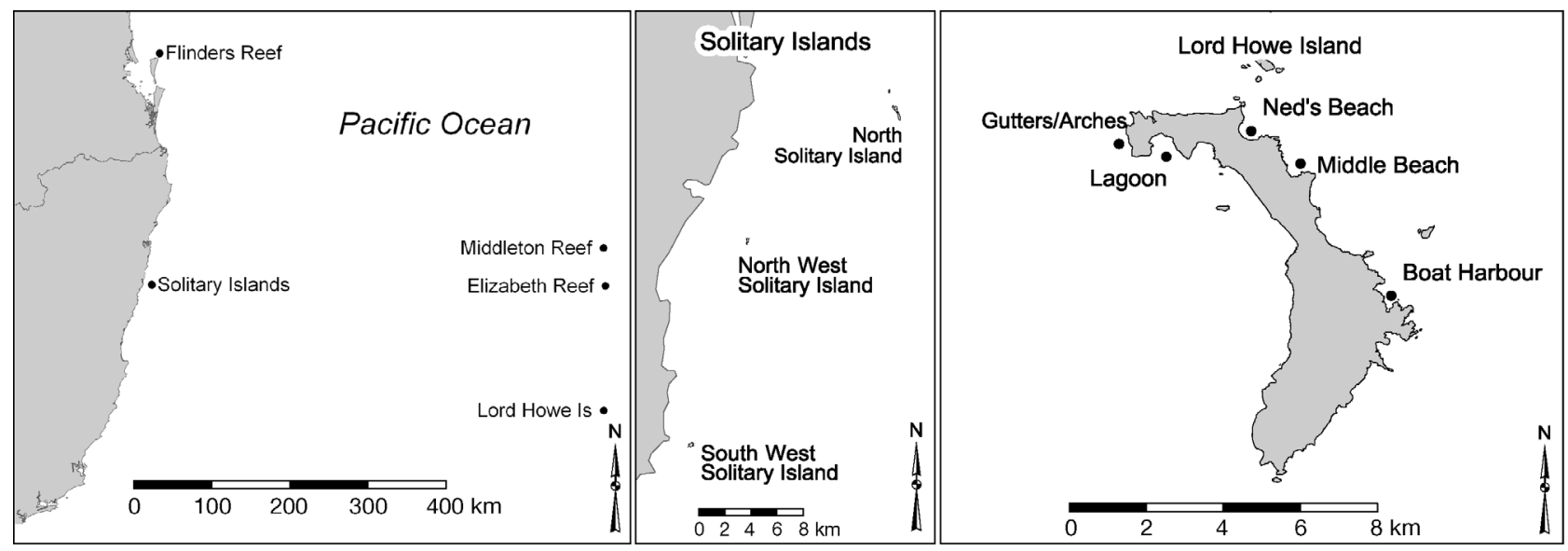

Fig. 1. Acropora solitaryensis. Sampling locations: Lord Howe Island and North, North West, and South West Solitary Islands. Sample sites at Lord Howe Island are indicated by black circles. Flinders Reef, Middleton Reef, and Elizabeth Reef were also visited for this study, but inadequate sample sizes were found at these locations

west), and not significantly genetically differentiated (based on $F_{\text {ST }}$ values calculated in FSTAT v. 2.9.3; Goudet 1995, 2002; data not shown). This resulted in pooling 2 pairs of sites: Gutters/Arches $\mathrm{n}=13$ and Lagoon $\mathrm{n}=7$; and Ned's Beach $\mathrm{n}=9$ and Middle Beach $\mathrm{n}=6$.

Branches of Acropora solitaryensis with a base ca. 5 $\mathrm{cm}$ in width were collected using SCUBA and fixed in $95 \%$ ethanol. DNA was extracted following a standard Proteinase $\mathrm{K}$ and isopropanol-precipitation extraction (Wilson et al. 2002). Eight Acropora microsatellite loci (Baums et al. 2005, van Oppen et al. 2007) were amplified using fluorescently labeled primers in 2 multiplex PCRs (Table A1 in Appendix 1). Samples were genotyped with an internal size standard (ET 400-R) on a MegaBACE 1000 capillary and scored using a MegaBACE Genetic Profiler v. 1.2.

\section{Data analysis}

GIMLET V. 1.3.3 (Valière 2002) was used to assess the ratio of clones $\left(N_{\mathrm{g}}\right)$ to unique genotypes sampled $(N)$ per population. If $\mathrm{P}_{\text {random }}$ was $\mathrm{p} \leq 0.01$ for identical genotypes, all but one sample in the putative clone sets was removed prior to analyses. Tests for linkage disequilibrium (LD) and Hardy-Weinberg equilibrium (HWE) were conducted in the web-based package GenePop v. 4.0 (Raymond \& Rousset 1995). Locus Amil2_018 was removed due to significant ( $p<$ 0.0001) LD with Amil2_010. As significant deviations from HWE were detected, Microchecker v. 2.2.3 (van Oosterhout et al. 2004) was used to test for the presence of null alleles, and significant null alleles were detected in many populations and loci (Table A1 in
Appendix 1). STRUCTURE v. 2.2 (Pritchard et al. 2000), a model-based clustering method, was used to visually represent a range of numbers of genetic clusters $(K)$. Burn-in was 100000 with 1000000 iterations for $K=1$ to $K=10$ replicated 5 times per $K$, and the most likely value of $K$ was determined following Evanno et al. (2005) (Fig. A1 in Appendix 1). GeneClass v. 2.0 (Piry et al. 2004) was used to detect first-generation immigrants under the following conditions: likelihood ratio $L_{\mathrm{home}} / L_{\max }$ with 10000 simulated individuals following the algorithm of Paetkau et al. (2004). This generated a probability of each individual being a putative migrant. Individuals with a $p$-value for being a migrant of $\leq 0.0001$ were removed from the original populations, and tested against the sampled populations. Genetix v. 4.05.2 (Belkhir et al. 1996-2004) was used to construct an individual-based principal coordinates analysis (PCA). Two Solitary Island outliers were removed from the data set to facilitate visual interpretation of the PCA.

\section{RESULTS}

A relatively high frequency of null alleles was observed for most loci studied (Table A1 in Appendix 1), which can skew HWE (and hence the inbreeding coefficient $F_{\text {IS }}$ ) (e.g. Chakraborty et al. 1992) and therefore affect data interpretation. Hence, these 2 genetic indices were not assessed here. Despite the presence of null alleles at most loci, moderate genetic diversity was detected at both locations (allelic richness $R=4.02-4.99$, expected heterozygosity $H_{\mathrm{e}}=$ $0.548-0.696)$ and this was not significantly different 
between locations for either parameter $(t$-tests, $\mathrm{p}=$ 0.25 and 0.68 , respectively). Low levels of clonality were recorded among samples from the Solitary Islands, but no clonality was observed at Lord Howe Island, where all samples were sexually produced (Table 1).

The most likely value of $K$ in STRUCTURE was 3, with 2 admixed genetic clusters dominant at the Solitary Islands, and another genetic cluster dominant at Lord Howe Island (Fig. 2). A small proportion of individuals at both the Solitary Islands and Lord Howe Island were admixed and showed assignment to the non-local genetic cluster (Fig. 2). The PCA also showed 2 distinct yet overlapping groups (Fig. 3), further supporting genetic differentiation between nearshore and offshore locations overlaid by a low level of gene flow.

Seven putative migrants $(p \leq 0.0001)$ were identified in GeneClass: one sampled at Lord Howe Island, and 6 sampled at the Solitary Islands (Table 2). The single migrant identified at Lord Howe Island had moderate re-assignment probabilities to each of the 3 Solitary Islands $(0.23-0.64)$. Four of the Solitary
Islands' putative migrants, all sampled at North West Solitary Island, could be assigned to one or 2 sites at Lord Howe Island at a low to moderate probability (0.16-0.36). The low relative bias of null alleles in assignment testing compared with other analyses (such as $F_{\mathrm{ST}}$; Carlsson 2008) provide confidence in these results despite the technical issues (i.e. null alleles). In addition, while the low sample sizes and the potential for unsampled Solitary Island or Lord Howe Island populations increase uncertainty in assignment, there are few other locations harbouring substantial Acropora solitaryensis populations in this region (e.g. Byron Bay; also see 'Discussion' regarding Middleton and Elizabeth Reefs) and this species is extremely rare to absent on the GBR.

\section{DISCUSSION}

The results of this study show that Acropora solitaryensis populations at Lord Howe Islands and the Solitary Islands are genetically differentiated, with the possibility of rare long-distance migration between these locations. These occasional dispersal events may play an important role in the persistence of these range-edge populations by maintaining genetic diversity as well as providing a mechanism for recolonization at an extirpated (or novel) site.

\section{Genetic diversity}

Low levels of clonality were recorded in populations at the nearshore Solitary Islands but the populations at

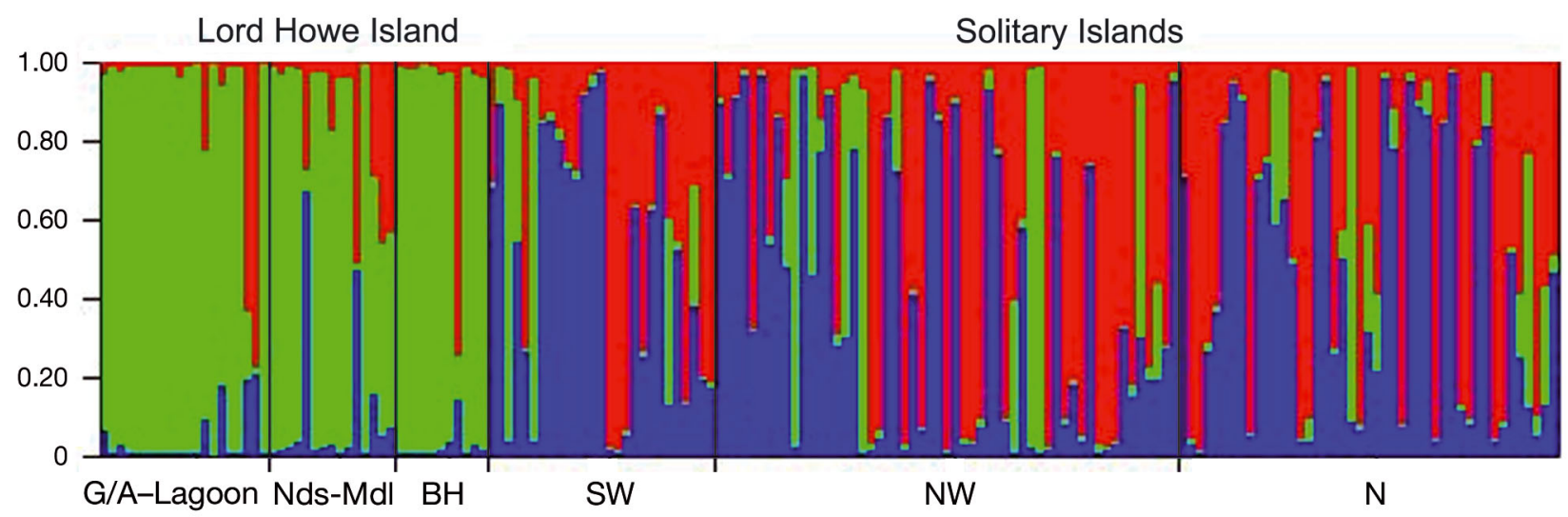

Fig. 2. Acropora solitaryensis. STRUCTURE bar plot for A. solitaryensis $(K=3)$. Each vertical line represents the assignment probability of a single individual to genetic cluster(s) without reference to where that individual was sampled 
Table 2. Acropora solitaryensis. Assignment of putative migrants. Site at which the individual was sampled (Site sampled), the p-value for being a migrant ( $\mathrm{p}$ migrant), the putative origin site(s), and the assignment probability for each site. LHI: Lord Howe Island; SOL: Solitary Island

\begin{tabular}{|lccc|}
\hline Site sampled & p migrant & Putative origin & Assignment $p$ \\
\hline LHI Boat & 0.0001 & SOL SW & 0.23 \\
Harbour & & SOL NW & 0.34 \\
& & SOL N & 0.62 \\
SOL SW & $<0.0001$ & None & $<0.01$ \\
SOL SW & $<0.0001$ & None & $<0.01$ \\
SOL NW & $<0.0001$ & LHI Ned's-Middle Beach & 0.16 \\
SOL NW & $<0.0001$ & LHI Ned's-Middle Beach & 0.13 \\
& & LHI Boat Harbour & 0.20 \\
SOL NW & $<0.0001$ & LHI Ned's-Middle Beach & 0.35 \\
& & LHI Boat Harbour & 0.36 \\
SOL NW & $<0.0001$ & LHI Boat Harbour & 0.21 \\
\hline
\end{tabular}

tions at the same latitude and separated by $\sim 1500 \mathrm{~km}$ of open ocean, genetic diversity was not substantially depressed for either population (Nakajima et al. 2012).

\section{Genetic differentiation and gene flow}

Two previous studies showed significant genetic differentiation of Acropora populations separated by extensive areas of open ocean and interpreted 'rare' (northwest Australia; Underwood 2009) or 'infrequent' (Japan; Nakajima et al. 2012) dispersal.

Lord Howe Island were completely sexual (Table 1). In contrast, the congener Acropora valida is highly clonal at Lord Howe Island (Ayre \& Hughes 2004). Fragmentation is a likely cause for clonality in Acropora solitaryensis, as it has a broadcast-spawning reproductive mode and does not develop asexually produced larvae (Harrison 2008, 2011). Despite the null alleles detected for most loci and populations, which cause an underestimation of genetic diversity, expected heterozygosity was moderately high $\left(H_{\mathrm{e}}>\right.$ 0.50) at both the Solitary Islands and Lord Howe Island. The $H_{\mathrm{e}}$ and $R$ detected in this study were within the range of values for Acropora species on the GBR and elsewhere (Underwood 2009, van Oppen et al. 2011, Richards \& van Oppen 2012). In addition, a similar high-latitude study in Japan on Acropora sp. 1 also found that for 2 subtropical loca-
In our study, the PCA (Fig. 3) as well as the STRUCTURE results (Fig. 2) support a similar conclusion: A. solitaryensis populations at the Solitary Islands and Lord Howe Island are genetically distinct, but with evidence of low levels of gene flow and admixture among them (Fig. 2, Table 2).

Migration from Lord Howe Island to the Solitary Islands and vice versa is consistent with potential larval dispersal pathways. For example, fish larvae can disperse from nearshore sites to Lord Howe Island (e.g. Patterson \& Swearer 2008); and a satellite-tracked drifter released during a coral spawning event at the Solitary Islands arrived at Lord Howe Island 25 d later (Wilson \& Harrison 1998), well within the extended competency period of Acropora solitaryensis (65 to $72 \mathrm{~d}$; Nozawa \& Harrison 2002). In addition, the formation of large gyres south of $32^{\circ} \mathrm{S}$

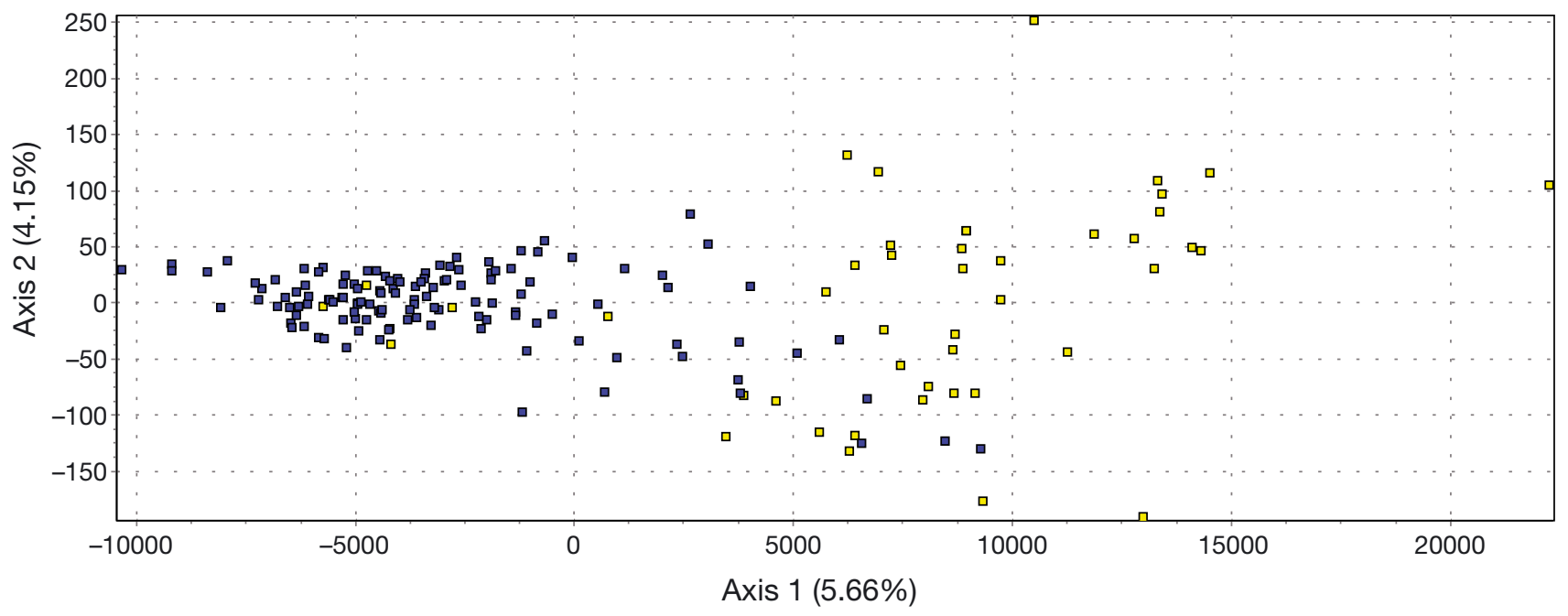

Fig. 3. Acropora solitaryensis. Principal coordinates analysis of Solitary Island (blue squares) and Lord Howe Island (yellow squares) samples 
could also provide transport for propagules in the opposite direction, from offshore to nearshore locations.

The STRUCTURE analysis indicated 3 as the most likely number of genetic clusters (Fig. A1 in Appendix 1) instead of 2 , and appears to result from 2 admixed clusters present in the Solitary Islands (Fig. 2). The relatively tight group formed by the Solitary Islands in the PCA and the nearly equal reassignment given to each of the 3 Solitary Island sites in GeneClass indicate genetic similarity among sites. Supporting this interpretation, the broadcast-spawning coral Goniastrea australensis showed low differentiation along several hundred kilometers of the subtropical Eastern Australian coastline (including the Solitary Islands) (Miller \& Ayre 2008). In addition, low population differentiation of broadcast-spawning Acropora species among a series of islands (over much larger spatial scales) has been detected at their northern range limit in Japan (Nishikawa et al. 2003, Nakajima et al. 2010). Many coral populations located along strong directional flows, such as the Kuroshio Current, the Agulhas Current (southeastern Africa), or the Eastern Australian Current have adequate dispersal and gene flow to prevent significant genetic differentiation over extended distances (100s of kilometres) (e.g. Ayre \& Hughes 2000, Ridgway et al. 2008, Nakajima et al. 2010). In contrast, significant population differentiation between sites at Lord Howe Island has previously been detected in 3 brooding and one broadcast-spawning reef coral species (Ayre \& Hughes 2004, Miller \& Ayre 2004, 2008, Noreen et al. 2009). In this study, the STRUCTURE results show that most Lord Howe Island samples belong to the same genetic cluster (Fig. 2), although the low sample size at Lord Howe Island prevents definitive interpretations on the population structure of $A$. solitaryensis among sites.

\section{Implications for genetic maintenance}

Our results are consistent with several possibilities regarding genetic maintenance of subtropical Acropora solitaryensis populations. The genetic diversity of A. solitaryensis in this region, measured with genetic markers that included null alleles, was generally on par with other Acropora species (e.g. Underwood 2009, van Oppen et al. 2011, Richards \& van Oppen 2012). One or more of several explanations could account for this, of which the most probable may be long-distance dispersal and/or interspecific hybridization. For example, a single successfully dispersed and ultimately reproductive migrant per generation can contribute substantially to genetic diversity in small populations (e.g. Mills \& Allendorf 1996, see also Sexton et al. 2011). Alternatively, hybridization between some Acropora species occurs occasionally (e.g. Willis et al. 2006) and range-edge populations of many plant and coral species may display more introgressive hybridization compared with populations in the core range (Thompson et al. 2010, Budd \& Pandolfi 2010). For example, at Lord Howe Island, likely Pocillopora damicornis $\times$ Stylophora pistillata hybrids were detected (Miller \& Ayre 2004). The difficulty of identifying unambiguously A. solitaryensis at some high latitude locations (Wallace 1999, C. C. Wallace pers. comm.) may reflect interspecific hybridization events.

\section{Implications for demographic maintenance}

Our data show consistent genetic distinctions, albeit with some apparent mixture, which indicate the demographic independence of geographically isolated subtropical Acropora solitaryensis populations. Previous studies of tropical coral species at Lord Howe Island predicted that coral populations would have 'extremely lengthy' replenishment time scales after extirpation (Ayre \& Hughes 2004, Miller \& Ayre 2008). Our results support this hypothesis, as do field observations: Middleton and Elizabeth Reefs, 180 and $235 \mathrm{~km}$ north of Lord Howe Island (respectively), harboured substantial populations of A. solitaryensis during the first detailed taxonomic study of these reefs in 1981 (Hutchings 1992, J. E. N. Veron pers. comm.). However, a severe crown-of-thorns starfish outbreak occurred at Middleton and Elizabeth Reefs in the mid-1980s (J. E. N. Veron pers. comm.), and no colonies of $A$. solitaryensis were observed at either location in 2007 during $>11 \mathrm{~h}$ diving at 7 sites and in suitable habitats (A. Noreen pers. obs.). This indicates either that $A$. solitaryensis is restricted to habitats at Elizabeth and Middleton Reefs that were not surveyed in 2007, or that the time scale for recolonization is $>20 \mathrm{yr}$. However, in the absence of complete simultaneous region-wide extinction, we hypothesize that replenishment will occur eventually (i.e. decades to centuries), as long as a source population within the region remains.

Acknowledgements. This project was funded by the International Society for Reef Studies/The Ocean Conservation Fellowship to A.M.E.N., who was supported during this project by a Southern Cross University Postgraduate Research Scholarship. We thank NSW Fisheries and NSW Marine 
Parks Authority for the necessary permits, and the Lord Howe Island Board for allowing this research. We thank Carden Wallace for diving and taxonomic assistance at Lord Howe Island, Greg Luker for creating the map, Lesa Peplow for laboratory assistance, and several anonymous reviewers for comments that significantly improved the manuscript.

\section{LITERATURE CITED}

Ayre DJ, Hughes TP (2000) Genotypic diversity and gene flow in brooding and spawning corals along the Great Barrier Reef, Australia. Evolution 54:1590-1605

Ayre DJ, Hughes TP (2004) Climate change, genotypic diversity and gene flow in reef-building corals. Ecol Lett $7: 273-278$

Baums IB, Hughes CR, Hellberg ME (2005) Mendelian microsatellite loci for the Caribbean coral Acropora palmata. Mar Ecol Prog Ser 288:115-127

Belkhir K, Borsa P, Chikhi L, Raufaste N, Bonhomme F (1996-2004) GENETIX 4.05, logiciel sous Windows TM pour la génétique des populations. Laboratoire Génome, Populations, Interactions, CNRS UMR 5000, Université de Montpellier II, Montpellier

Budd AF, Pandolfi JM (2010) Evolutionary novelty is concentrated at the edge of coral species distributions. Science 328:1558-1561

> Carlsson J (2008) Effects of microsatellite null alleles on assignment testing. J Hered 99:616-623

> Chakraborty R, De Andrade M, Daiger SP, Budowle B (1992) Apparent heterozygote deficiencies observed in DNA typing data and their implications in forensic applications. Ann Hum Genet 56:45-57

Eckert CG, Samis KE, Lougheed SC (2008) Genetic variation across species' geographic ranges: the central-marginal hypothesis and beyond. Mol Ecol 17:1170-1188

Evanno G, Regaut S, Goudet J (2005) Detecting the number of clusters of individuals using the software STRUCTURE: a simulation. Mol Ecol 14:2611-2620

Goudet J (1995) FSTAT (version 1.2), a program to estimate and test gene diversities and fixation indices. J Hered 86: $485-486$

Goudet J (2002) FSTAT version 2.9.3.2. Available at www2. unil.che/popgen/softwares/fstat.htm

> Hardie DC, Hutchings JA (2010) Evolutionary ecology at the extremes of species' ranges. Environ Rev 18:1-20

Harriott VJ, Banks SA, Mau RL, Richardson D, Roberts LG (1999) Ecological and conservation significance of the subtidal rocky reef communities of northern New South Wales, Australia. Mar Freshw Res 50:299-306

> Harrison PL (2008) Coral spawn slicks at Lord Howe Island, Tasman Sea, Australia: the world's most southerly coral reef. Coral Reefs 27:35

Harrison PL (2011) Sexual reproduction of scleractinian corals. In: Dubinsky Z, Stambler N (eds) Coral reefs: an ecosystem in transition. Springer, Dordecht, p 59-85

Hutchings P (ed) (1992) Reef biology: a survey of Elizabeth and Middleton reefs, South Pacific. Kowari 3. Australian National Parks and Wildlife Service, Canberra

> Kawecki TJ (2008) Adaptation to marginal habitats. Annu Rev Ecol Evol Syst 39:321-342

Miller KJ, Ayre DJ (2004) The role of sexual and asexual reproduction in structuring high latitude populations of the reef coral Pocillopora damicornis. Heredity 92: $557-568$
Miller KJ, Ayre DJ (2008) Protection of genetic diversity and maintenance of connectivity among reef corals within marine protected areas. Conserv Biol 22:1245-1254

Mills SL, Allendorf FW (1996) The one-migrant-pergeneration rule in conservation and management. Conserv Biol 10:1509-1518

> Nakajima Y, Nishikawa A, Iguchi A, Sakai K (2010) Gene flow and genetic diversity of a broadcast-spawning coral in northern peripheral populations. PLoS ONE 5:e11149

> Nakajima Y, Nishikawa A, Iguchi A, Sakai K (2012) Regional genetic differentiation among northern highlatitude island populations of a broadcast-spawning coral. Coral Reefs 31:1125-1133

> Nishikawa A, Katoh M, Sakai K (2003) Larval settlement rates and gene flow of broadcast-spawning (Acropora tenuis) and planula-brooding (Stylophora pistillata) corals. Mar Ecol Prog Ser 256:87-97

Noreen AME, Harrison PL, van Oppen MJH (2009) Genetic diversity and connectivity in a brooding reef coral at the limit of its distribution. Proc R Soc Lond B Biol Sci 276: 3927-3935

Nozawa Y, Harrison PL (2002) Larval settlement patterns, dispersal potential, and the effect of temperature on settlement of larvae of the reef coral, Platygyra daedalea, from the Great Barrier Reef. Proc 9th Int Coral Reef Symp, Bali 1:409-415

> Nozawa Y, Harrison PL (2007) Effects of elevated temperature on larval settlement and post-settlement survival in scleractinian corals, Acropora solitaryensis and Favites chinensis. Mar Biol 152:1181-1185

Paetkau D, Slade R, Burden M, Estoup A (2004) Genetic assignment methods for the direct, real-time estimation of migration rate: a simulation-based exploration of accuracy and power. Mol Ecol 13:55-65

Patterson HM, Swearer SE (2008) Origin of yellowtail kingfish, Seriola lalandi, from Lord Howe Island, Australia, inferred from otolith chemistry. NZ J Mar Freshw Res 42: 409-416

Piry S, Alapetite A, Cornuet JM, Paetkau D, Baudouin L, Estoup A (2004) GeneClass2: a software for genetic assignment and first-generation migrant detection. J Hered 95:536-539

> Pritchard JK, Stephen M, Donnolley P (2000) Inference of population structure using multilocus genotype data. Genetics 155:945-959

Raymond M, Rousset F (1995) GENEPOP (version 1.2): population genetics software for exact tests and ecumenicism. J Hered 86:248-249

Richards ZT, van Oppen MJH (2012) Rarity and genetic diversity in Indo-Pacific Acropora corals. Ecol Evol 2: 1867-1888

Ridgway T, Riginos C, Davis J, Hoegh-Guldberg O (2008) Genetic connectivity patterns of Pocillopora verrucosa in southern African Marine Protected Areas. Mar Ecol Prog Ser 354:161-168

> Sexton JP, Strauss SY, Rice KJ (2011) Gene flow increases fitness at the warm edge of a species' range. Proc Natl Acad Sci USA 108:11704-11709

Thompson JD, Gaudeul M, Debussche M (2010) Conservation value of sites of hybridization in peripheral populations of rare plant species. Conserv Biol 24:236-245

Underwood JN (2009) Genetic diversity and divergence among coastal and offshore reefs in a hard coral depend on geographic discontinuity and oceanic currents. Evol Appl 2:222-233 
Underwood JN, Smith LD, van Oppen MJH, Gilmour PJ (2009) Ecologically relevant dispersal of corals on isolated reefs: implications for managing resilience. Ecol Appl 19:18-29

Valière N (2002) GIMLET: a computer program for analysing genetic individual identification data. Mol Ecol Notes 2: $377-379$

van Oosterhout C, Hutchinson WF, Wills DPM, Shipley P (2004) MICRO-CHECKER: software for identifying and correcting genotyping errors in microsatellite data. Mol Ecol Notes 4:535-538

van Oppen MJH, Underwood JN, Muirhead AN, Peplow L (2007) Ten microsatellite loci for the reef-building coral Acropora millepora (Cnidaria, Scleractinia) from the Great Barrier Reef, Australia. Mol Ecol Notes 7:436-438 van Oppen MJH, Peplow LM, Kininmonth S, Berklemans R (2011) Historical and contemporary factors shape the population genetic structure of the broadcast spawning coral, Acropora millepora, on the Great Barrier Reef. Mol Ecol 20:4899-4914

Wallace CC (1999) Staghorn corals of the world: a revision of the genus Acropora. CSIRO Publishing, Collingwood

Willis BL, van Oppen MJH, Miller DJ, Vollmer SV, Ayre DJ (2006) The role of hybridization in the evolution of reef corals. Annu Rev Ecol Evol Syst 37:489-517

Wilson JR, Harrison PL (1998) Settlement-competency periods of larvae of three species of scleractinian corals. Mar Biol 131:339-345

Wilson JR, Harrison PL (2003) Spawning patterns of scleractinian coals at the Solitary Islands - a high latitude coral community in eastern Australia. Mar Ecol Prog Ser 260: $115-123$

Wilson K, Li Y, Whan V, Lehnert S, and others (2002) Genetic mapping of the black tiger shrimp Penaeus monodon with amplified fragment length polymorphism. Aquaculture 204:297-309

\section{Appendix 1}

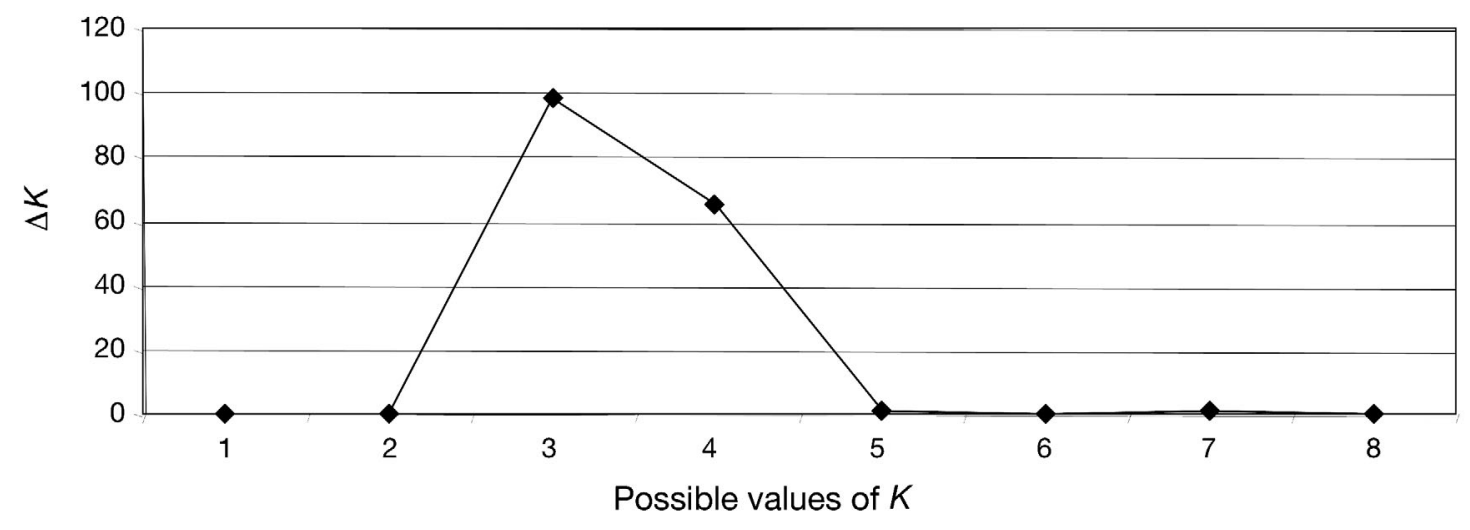

Fig. A1. $\Delta K$ values for STRUCTURE analysis 
Table A1. Summary of Acropora solitaryensis data per population and locus. Number of alleles, observed heterozygosity $\left(H_{\mathrm{o}}\right)$, expected heterozygosity $\left(H_{\mathrm{e}}\right)$, inbreeding coefficients $\left(F_{\mathrm{IS}}\right)$, and loci with probable null alleles (Nulls)

\begin{tabular}{|c|c|c|c|c|c|c|c|}
\hline & Locus & No. of alleles & $H_{\mathrm{o}}$ & $H_{\mathrm{e}}$ & $F_{\text {IS }}$ & $\mathrm{p}$ & Nulls \\
\hline \multicolumn{8}{|l|}{ Lord Howe Island } \\
\hline \multirow[t]{7}{*}{ Gutters/Arches-Lagoon } & Amil2_002 & 7 & 0.350 & 0.781 & 0.569 & 0.000 & Yes \\
\hline & Amil2_010 & 7 & 0.550 & 0.689 & 0.225 & 0.002 & Yes \\
\hline & Amil2_006 & 5 & 0.300 & 0.466 & 0.378 & 0.005 & Yes \\
\hline & Amil2_023 & 2 & 0.250 & 0.219 & -0.070 & 0.371 & No \\
\hline & Amil2_022 & 10 & 0.650 & 0.849 & 0.258 & 0.000 & Yes \\
\hline & Amil5_028 & 9 & 0.895 & 0.816 & -0.118 & 0.755 & No \\
\hline & Apam3_166 & 13 & 0.737 & 0.846 & 0.156 & 0.007 & Yes \\
\hline \multicolumn{8}{|l|}{ Lord Howe Island } \\
\hline \multirow[t]{7}{*}{ Ned's Beach-Middle Beach } & Amil2_002 & 6 & 0.667 & 0.796 & 0.195 & 0.124 & No \\
\hline & Amil2_010 & 6 & 0.467 & 0.644 & 0.307 & 0.073 & Yes \\
\hline & Amil2_006 & 3 & 0.267 & 0.604 & 0.582 & 0.002 & Yes \\
\hline & Amil2_023 & 3 & 0.133 & 0.127 & -0.018 & 0.969 & No \\
\hline & Amil2_022 & 10 & 0.533 & 0.880 & 0.432 & 0.000 & Yes \\
\hline & Amil5_028 & 9 & 0.733 & 0.833 & 0.154 & 0.034 & No \\
\hline & Apam3_166 & 11 & 0.500 & 0.885 & 0.465 & 0.000 & Yes \\
\hline \multicolumn{8}{|l|}{ Lord Howe Island } \\
\hline \multirow[t]{7}{*}{ Boat Harbour } & Amil2_002 & 7 & 0.455 & 0.744 & 0.420 & 0.048 & Yes \\
\hline & Amil2_010 & 6 & 0.545 & 0.657 & 0.216 & 0.070 & No \\
\hline & Amil2_006 & 3 & 0.182 & 0.483 & 0.652 & 0.007 & Yes \\
\hline & Amil2_023 & 2 & 0.364 & 0.397 & 0.096 & 0.101 & No \\
\hline & Amil2_022 & 8 & 0.889 & 0.815 & -0.032 & 0.891 & No \\
\hline & Amil5_028 & 11 & 0.818 & 0.860 & 0.130 & 0.603 & Yes \\
\hline & Apam3_166 & 9 & 0.636 & 0.831 & 0.278 & 0.044 & No \\
\hline \multicolumn{8}{|l|}{ Solitary Island } \\
\hline \multirow[t]{7}{*}{ South West } & Amil2_002 & 9 & 0.760 & 0.846 & 0.121 & 0.018 & No \\
\hline & Amil2_010 & 2 & 0.111 & 0.226 & 0.521 & 0.037 & No \\
\hline & Amil2_006 & 6 & 0.360 & 0.626 & 0.442 & 0.005 & Yes \\
\hline & Amil2_023 & 1 & - & - & - & - & - \\
\hline & Amil2_022 & 7 & 0.261 & 0.524 & 0.518 & 0.000 & Yes \\
\hline & Amil5_028 & 8 & 0.680 & 0.748 & 0.111 & 0.008 & Yes \\
\hline & Apam3_166 & 9 & 0.263 & 0.852 & 0.704 & 0.000 & Yes \\
\hline \multicolumn{8}{|l|}{ Solitary Island } \\
\hline \multirow[t]{7}{*}{ North West } & Amil2_002 & 8 & 0.611 & 0.850 & 0.290 & 0.000 & Yes \\
\hline & Amil2_010 & 4 & 0.184 & 0.417 & 0.567 & 0.000 & Yes \\
\hline & Amil2_006 & 6 & 0.241 & 0.525 & 0.548 & 0.000 & Yes \\
\hline & Amil2_023 & 2 & 0.000 & 0.036 & 1.000 & 0.009 & Yes \\
\hline & Amil2_022 & 8 & 0.309 & 0.554 & 0.450 & 0.002 & Yes \\
\hline & Amil5_028 & 13 & 0.755 & 0.839 & 0.112 & 0.000 & Yes \\
\hline & Apam3_166 & 12 & 0.278 & 0.894 & 0.697 & 0.000 & Yes \\
\hline \multicolumn{8}{|l|}{ Solitary Island } \\
\hline \multirow[t]{7}{*}{ North } & Amil2_002 & 11 & 0.705 & 0.850 & 0.182 & 0.004 & Yes \\
\hline & Amil2_010 & 5 & 0.190 & 0.357 & 0.476 & 0.000 & Yes \\
\hline & Amil2_006 & 5 & 0.227 & 0.500 & 0.553 & 0.000 & Yes \\
\hline & Amil2_023 & 1 & - & - & - & - & - \\
\hline & Amil2_022 & 9 & 0.378 & 0.568 & 0.344 & 0.000 & Yes \\
\hline & Amil5_028 & 11 & 0.750 & 0.802 & 0.076 & 0.031 & Yes \\
\hline & Apam3_166 & 16 & 0.432 & 0.897 & 0.528 & 0.000 & Yes \\
\hline
\end{tabular}

Editorial responsibility: Charles Birkeland, Honolulu, Hawaii, USA
Submitted: November 5, 2012; Accepted: July 12, 2013

Proofs received from author(s): September 25, 2013 